THURSDAY, APRIL 16, 1885

\section{A SCIENTIFIC UNIVERSITY}

$\mathrm{F}^{\mathrm{NGLAND}}$ is but just beginning to feel the wave of progress in the question of University organisation that has been sweeping over the rest of the world. University reform as understood in England means a rather fitful movement from within to lift the teaching and methods of the older Universities a little out of the mediævalism that has been settling down upon them. The true University reform has meantime been going on outside in the spread of scientific teaching far away from the quiet collegiate quadrangles, in the establishment of new Universities and University Colleges in the centres of provincial life. It is very hard to make an Englishman believe that there is any subject in which he is not leading the progress of the world. Yet let him look at Germany, at France, at America, and consider what is being done abroad, before he passes his complacent comment on the feeble reforms at home. Let him look at the City of Berlin with its $1,123,000$ inhabitants, its teaching University with 6000 students; and then turn to the City of London with its 4,000,000 inhabitants, without a teaching University at all, and having some 2000 students in all under training at its two best educational establishments. The contrast does not stop here, as any person acquainted with the University systems of Europe knows only too well. The fact is that England is wofully behind the rest of the world in the organisation of the higher scientific education. Its Government is absolutely indifferent to the most crying needs in this direction. What does the British Government do for the higher scientific teaching, or for the promotion of the reorganisation of our existing Universities on the modern scientific basis? An annual grant of a few thousands to the South Kensington Normal School, a subsidy of about $25,000 l$. a year to the Scottish Universities, and one of about 12,500l. a year to the Welsh University Colleges, whereof perhaps one-half goes to the promotion of science, represent the net result. True a Government some fifty years ago founded the Examining Board, miscalled the University of London, and another Government, some fifteen years ago, gave 90,000/. to help the University of Glasgow to complete its buildings. But for the University movement throughout England, such as it is to-day, England owes nothing to one single statesman or Government; it is due to individual and local effort, aided it is true, but on the most minute scale, by the action of one or two of the more liberal corporate bodies. It is well, then, that Englishmen should have the opportunity of reading, as they may do in the present number of NATURE, what has been done in a single small province of Europe, in a city of only ro4,000 inhabitants, in the equipment of a great University on modern lines. The completeness of the equipment, and the magnificence of the buildings of the new University of Strasburg are truly startling. It is to the divine right of learning knowledge, not to the divine right of ruling wrong that these modern palaces are erected. The Zeit Geist has indeed wrought revenges in the honour thus rendered to science and to philosophy, to VOL. XXXI.-NO. 807 literature and to art. Imperial Germany unites with her own province of Alsace-Lorraine to bestow $640,000 l$. upon the new University buildings, and to increase its existing endowments by a sum of $42,000 l$. per annum. Nor is this a solitary fact. During the last nine years France has spent nearly $\mathrm{I}, 000,000 \mathrm{l}$. per annum on increasing and reorganising her University institutions. What has England to show against this? The Imperial Government has with the exception of the little Scotch and WeIsh grants named above, done literally nothing. All else that has been done has been done mainly by a few individuals with great difficulty, on a very limited scale, in the teeth of all sorts of uninteliigent opposition. Oxford Convocation consents, amid fierce debate, to spend I0,000/. on a physiological laboratory. Strasburg, in the meantime, has quietly spent 13,500 . for the same purpose; and this (Fig. I 5, p. 56I) is the smallest of the splendid group of institutes and laboratories in the new University. The Corporation of Nottingham - the only Corporation that has shown public spirit in this direction-has spent some 70,000l. upon an institution which includes a Natural History Museum and a Public Library, and a University College. Nottingham, has a population of 186,000 souls. At Strasburg, with a population of I04,000, a sum equal to this has been spent on institutes of chemistry and anatomy alone (Figs. 5 and 9, pp. 559-60), and nine times as much on the rest of the University buildings and fittings. The Corporation of Liverpool very generously contrived to accommodate its new University College in a disused lunatic asylum. But the whole of the buildings of Liverpool University College would go twice over into the Strasburg Institute of Chemistry (Fig. 5, p. 559). At Cardiff, the Town Council, after an attempt to thrust its University College into a still less suitable site, agreed to rent to it an old infirmary for its various scientific laboratories and lecturerooms; but the Strasburg University possesses twelve buildings, every one of which is as large as the Cardiff building, and infinitely better adapted to the purpose. Owens College, the Mason College, the Firth College, owe nothing to corporate help: they are sustained by private benefactions. The Yorkshire College is also innocent of any municipal support. At Bristol, with a population of about 200,000 souls-nearly double Strasburg-funds privately subscribed to about I I, Oool. have resulted in a ragged fragment of ill-assorted rooms to accommodate the local University College; the entire buildings for literature, science, and medicine being less than half the size of the Institute of Physics (Fig. 6, p. 559) at Strasburg. Lastly, the city of Newcastle-on-Tyne, with a population of $\mathrm{5} 50,000$, relegates its Science College to the cellars of a Mining Institution, where it is effectually buried from public notice. There is nothing at Strasburg comparable to this.

Englishmen will awake some day to the astounding neglect and apathy that have prevailed and still prevail; and then perhaps some statesman will think it worth his while to turn from endless party squabbles to useful national work. To reorganise the higher education of this country on a scale commensurate with that of other European countries, and o co-ordinate it with the rest of our educational system, and to equip it with buildings and appliances adequate $o$ the needs of the time would 
be a task of truly national importance, and one which must sooner or later be undertaken. It is a task befitting the ambition of an enlightened statesman. The Minister who shall succeed in the task will leave behind him in the memories of the nation a monument more enduring than marble.

\section{TIMBUKTU}

Timbuktu: Reise durch Marokko, die Salhara und den Sudan. Von Dr. Oslsar Lenz. 2 vols. (I.eipzig, I 884.)

$A S$ we have already intimated, Dr. Lenz is about to A set out on a new expedition, the purpose of which is to explore the unknown region lying between the upner waters of the Nile and the northern bend of the Congo. The reputation of a scientific explorer already carned by Dr. Lenz through his researches in the Ogoway basin will be much enhanced by the present work, embodying the results of a very successful expedition to North-West Africa, undertaken in the years $1879-80$ on behalf of the German African Society. His original commission was restricted to a visit to Marokko, chiefly with a view to a more thorough survey of the Atlas highlands than had hitherto been effected by recent travellers in that still little known region. But the sanction of the Society was easily obtained to extend the field of his operations, so as, if possible, to cmbrace the still less known section of the Sahara lying between Marokko and the Niger. Timbuktu, the southern teminus of the caravan routes across this part of the desert, thus became the main goal of the expedition. The famous "Queen of the Wilderness" had been reached during the present century only by three European travellers-Major Laing in 1826 , Renć Caillé in 1828 , and Barth in 1853 . To these illustrious names must now be added that of Oskar Lenz, who not only chtered the place on July I, 1880 , mainly by a new route from the north, but also for the first time made his way thence westwards through the Fulah and Negro States of Moássina (Massina) and Bambara down the Sencgal river to the $\Lambda$ tlantic coast at St. Louis, capital of the French possessions in Senegambia. Hence the most important result of the journey has been to show that Timbulktu, hitherto regarded as practically inaccessible to Europeans, may be reached both through Marokko from the north and through the Senegal basin from the wost.

It will be thus seen that the experition naturally comprises two distinct sections-Marokko and the $\Lambda$ tlas ranges as far as the Draa basin, which are exhaustively dealt with in the first volume; the western Sahara and Sudan described in the second volume, which moreover contains some valuable supplementary matter on the French scttlements in Senegambia and on the physical constitution of the Sahara, besides an extremely interest ing account of the present political and social relations in Timbuktu. Dr. Lcnz travelled with a very small suite, limited to his interpreters, Haj Ali Butaleb and Christobal Benitez, and his trusty Marokkan attendant Kaddur. But, thanks partly to a letter of recommendation from Muley Hassan, Sultan of Marokko, partly to the character which he assumed of a Mussulman physician, he managed to pass without much scrious risk through the turbulent and fanatical Arab, Berber, Fulah, and Negro tribes cncountered along the route. llence his conclusion, shared in by some other experienced explorers, that single travellers hampered by a minimum of impedimenta are likely to prove more successful in Africa than elaborately equipped expeditions, at least where the object is mere geographical discovery rather than extensive biological and ethnographic collections.

From the observations made at various points in recent times it has become more and more evident that the Sahara can no longer be regarded as having been a marine basin at least since the carly Tertiary epoch. The theory may be said to have received its coup de grace from Dr. Lenz, who plainly shows that the whole of the western section traversed by him is not a depression, as has been assumed, but an irregular plateau standing in the north at a mean elevation of from 800 to 1000 feet, and even at Taudeni, its lowest level, still maintaining an altitude of 400 or 500 feet above the Atlantic. The surface is varied with stony and sandy tracts, the so-called "areg" or "igidi," which have nothing in common with marine sedimentary deposits, but have, in fact, been produced by the weathering of sandstone, quartz, and carboniferous limestones, which appear to be the prevailing formations. It is thus evident that this part of the desert has been dry land for vast ages, and the same conclusion must be inferred from the numerous dried-up watercourses, whose deep channels are distinctly the effect of erosion. These wadies, many of which seem to have been flooded within the last few thousand years, radiate from the central highlands north and north-east to the Mediterranean, east to the Nile, south to the Tsad and Niger, west to the Atlantic. Hence down to comparatively recent times the Sahara was a well-watered and wooded region thickly inhabited by agricultural and pastoral communities, themselves the descendants or successors of still more primitive peoples, the contemporaries of Palæolithic and Neolithic man in other parts of the globe. In the Taudeni district, about $20^{\circ} \mathrm{N}$, under the meridian of Timbuktu, Dr. Lenz discovcred some implements of hard greenstone well worked and polished, and similar objects have also been found by Gerhard Rohlfs as far west as the Kufara oasis south of Tripolitana. The Asiatic camel is here a comparatively recent intruder, preceded by the Garamantian war-horse and by the clephant, trained also to war by the native Numidians and Phonician Carthaginians. The crocodile even still survives in many of the pools and lakelets here and there marking the course of mighty streams, which formerly sent their perennial floods down to the surrounding marine basins.

Apart from possible cosmic infuences, our author attributes the great change that has taken place within the historic period, not with Peschel to the dry north-east Polar winds, which in the Sahara yield to the prevailing northern and north-western atmospheric currents, but largely to the reckless destruction of the woodlands which at one time covered vast tracts in this now arid and treeless region. With the vegetation disappeared the moisture; all the large fauna became extinct, and the settled populations were succeeded by nomad tribes of Berber (Hamitic) stock, joined later on by Semites from the Arabian Peninsula. 